\title{
Ally or enemy? \\ Cyberworld and adolescents' well-being
}

\author{
A. Kwiatkowska ${ }^{1}$ \\ ${ }^{1}$ Institute of Psychology, Polish Academy of Sciences, \\ 1 Jaracza Str., 00-378 Warsaw, Poland
}

\author{
Author: \\ Kwiatkowska Anna \\ e-mail: akwiatkowska@psych.pan.pl \\ Scopus AuthorId: 36912691100 \\ ORCID: 0000-0002-5867-7079 \\ Copyright: \\ (C) The Author (2019). \\ Published by Herzen State \\ Pedagogical University of Russia.
}

Abstract. Close to $90 \%$ of adolescents are using digital technology and spend much of their day texting, exploring web sites, interacting online with peers or strangers, gaming online, downloading films or music, watching videos online, blogging, shopping online, etc. Many adults express their concern about whether adolescents' frequent use of new technologies is having a negative influence on their development. The purpose of this paper is to examine the possible consequences of digital technology use on the well-being of adolescents. The data about the impact of modern technology and forms of communication on adolescents is inconclusive, partly because of some shortcomings of study designs, partly due to rapid changes in digital technology. The most recent research is reviewed. The paper opens with the presentation of basic facts and numbers about using digital technology by adults and adolescents in the world, with a focus on social media. Several motives for children's internet use are listed: the affinity with a computer, seeking information, recreational reasons, avoidance of boredom, making new friends and socialize with old ones. Next, the most popular parents' concerns are presented, such as fear about adolescents' online interactions (with whom), cyberbullying, separation from real life, experimenting with identities, etc. Parents' fears have been confronted with scientific findings. It occurred that some concerns are justified (e.g., the problem of cyberbullying, multitasking, or sleep disruption). Other fears are not confirmed by data (e.g., concerning social development or parent-child relations). Also, the evidence suggests that moderate use of digital technology tends to be beneficial for children's mental well-being, while no use or too much use can have a small negative impact.

Keywords: adolescence, digital technology use, internet, social media, online dangers, online benefits. 


\title{
Союзник или враг? Киберпространство и благополучие подростков
}

\author{
А. Квятковска ${ }^{1}$ \\ ${ }^{1}$ Институт психологии, Польская академия наук, \\ 00-378, Польша, Варшава, ул. Ярача, 1
}

\section{Сведения об авторе:}

\section{Квятковска Анна}

e-mail: akwiatkowska@psych.pan.pl

Scopus AuthorId: 36912691100

ORCID: 0000-0002-5867-7079

(C) Автор (2019).

Опубликовано Российским

государственным педагогическим

университетом им. А. И. Герцена.

Аннотация. Почти $90 \%$ подростков используют цифровые технологии и проводят большую часть своего дня, отправляя текстовые сообщения, исследуя вебсайты, взаимодействуя в интернете со сверстниками или незнакомыми людьми, играя в онлайн-игры, скачивая фильмы или музыку, просматривая видео в интернете, ведя блог, делая покупки в интернете и т. д. Многие взрослые выражают озабоченность по поводу того, не оказывает ли частое использование подростками новых технологий негативного влияния на их развитие. Целью данной статьи является изучение возможных последствий использования цифровых технологий для благополучия подростков. Данные о влиянии современных технологий и форм коммуникации на подростков противоречивы, отчасти из-за некоторых недостатков исследовательских подходов и процедур, отчасти из-за быстрых изменений в цифровых технологиях. В статье рассматриваются новейшие исследования. Статья начинается с представления основных фактов об использовании цифровых технологий взрослыми и подростками в мире, с акцентом на социальные медиа. Перечислены несколько мотивов использования детьми интернета: доступность компьютера, поиск информации, рекреационные причины, избегание скуки, поиск новых друзей и общение со старыми. Далее представлены наиболее популярные опасения родителей, такие как страх перед онлайн-взаимодействиями подростков (с кем?), кибербуллинг, отрыв от реальной жизни, экспериментирование с идентичностями и др. Страхи родителей сопоставляются с научными открытиями. Оказалось, что некоторые опасения оправданы (например, проблема кибербуллинга, многозадачности или нарушения сна). Другие опасения не подтверждаются результатами исследований (например, нарушения социального развития или детско-родительских отношений). Кроме того, данные свидетельствуют о том, что умеренное использование цифровых технологий, как правило, полезно для психического благополучия детей, в то время как отсутствие или слишком интенсивное использование может иметь некоторое негативное влияние.

Ключевые слова: подростковый возраст, использование цифровых технологий, интернет, социальные медиа, опасности онлайн-технологий, преимущества онлайн-технологий. 


\section{Problem}

The internet has become an integral and irreplaceable part of our daily lives. It becomes an indispensable modern-day tool for shopping, study, research, communication, and staying in touch with friends and family members through numerous applications ranging from Wikipedia to Facebook, Twitter, Instagram, etc. With the rapid changes in wireless internet technologies such as WI-FI, 3G, 4G, and now $5 \mathrm{G}$, the internet has become readily accessible to individuals across all socioeconomic groups. In Europe, household internet access rose from $55 \%$ in 2007 to $89 \%$ in 2018, and internet access through a mobile device also increased from $36 \%$ in 2012 to $69 \%$ in 2018 (Eurostat 2019). Personal computers and smartphones have become popular among children and adolescents. Adolescents spend much of their day texting, exploring the web, and interacting with their mobile devices. Research suggests that the internet can be beneficial for young people. It offers adolescents plenty of opportunities for their selfdevelopment, such as the chance to establish deep connections with their peers and help in achieving academic success.

However, digital technology and - in particular - the internet, may turn into sinister force which may jeopardize children's psychosocial well-being. Problematic internet use, compulsive internet use, internet abuse, pathological internet use, and internet addiction are the most frequently employed terms to describe dangers created by internet use (Cash, Rae, Steel, Winkler 2012). Children might receive emails or other messages that are embarrassing, upsetting, or hostile so that they are susceptible to online harassment. In the case that children give out personal information such as their address or arrange an encounter with a person who cannot be trusted, they are subject to the potential danger of being harassed offline. Also, physical well-being may be at risk, since the negative consequences of the digital media on physical health may range from obesity to even death by accident, with the most significant danger associated with smartphones posed by use while crossing the road. The excessive use of the internet by children has become a subject of great concern for many parents and teachers.

In this paper, I would like to discuss possible consequences of digital technology use on children's well-being. Generally speaking, digital technology presents for the youth a multitude of opportunities along with many risks. There is no surprise that attitudes of adults towards mobile devices and internet use by their children are somehow ambivalent. On the one hand, many parents are happy when seeing that their children - even very small kids - are interested in the digital world, on the other hand, there are many parents who afraid of potential bad influence which excessive use of the internet may have. The question of whether such technology is good or bad to our children is not easy to be answered, even by scholars. Existing knowledge based on research carried out across domains (psychology, pedagogy, health science, etc.) does not bring unambiguous solutions to this problem, since accumulated evidence is largely inconclusive. Why is that?

\section{Research Limitations}

First of all, most of the research relies heavily, if not almost exclusively, on observational and correlational study designs. Correlational studies show associations between such phenomena as, for example, a high amount of time spent on the internet and low self-esteem, or depression. We must not jump to the conclusion that internet abusers are at risk for psychological disorders, because we are not able to infer from correlation what is the cause, and what is the outcome (unless we have a good theory). Experimental designs are needed to expand our understanding of these phenomena. The other problem is that research is based on self-report data, quite often biased in many ways. We need to go beyond self-report evidence since unobtrusive monitoring of online activities is now available through mobile applications and wireless sensors. Also, we have to be cautious as regards a period when a given study was done. We cannot compare evidence from studies carried out at the end of the XX century, and studies 
performed 20 years later. This is due to the fact that the development of digital technology is proceeding extremely fast, introducing new instruments and new ways of using them. This means that researchers have to catch up with changes in technology devices and the inevitable transformation of users. Lastly, each country has its specificity concerning access to digital technology and its use which are related to economic, cultural, and other factors (Pew Research Center 2019).

\section{Why Adolescence?}

Anyway, keeping these reservations about research limitations in mind, let us look at the recent findings providing by scholars from all over the world. But first, I am going to explain why my focus here is on the adolescent period, that is, broadly defined as between 12 and 20 years of age. There are at least three reasons for that.

Firstly, there is a close congruence between ways of how mobile devices are typically used and developmental tasks required during adolescence. Adolescence has long been viewed as a time of self-exploration and discovery of one's place in the social world (Erikson 1968). Adolescents face with the challenge of mastering critical developmental tasks such as building healthy relationships, gaining autonomy, forming their identity, and transitioning to young adulthood-while fully immersed in the digital world (George, Odgers 2015). For them the most important thing now is to belong to a peer group, to make friends and be with them in constant contact, and to define themselves in terms of belongingness and uniqueness at the same time. During the process of identity formation, adolescents become increasingly self-aware of their abilities, limitations, and defining qualities while addressing critical questions about their values and roles in the social world. Mobile technologies, providing tools for communication, facilitate connectivity with peers, and allow to establish one's place in the social world.

Secondly, adolescents are seen as a potentially vulnerable subgroup given the dramatic social, cognitive, biological, and psychological changes that characterize this period. If any danger in cyberworld exists, the harm could be done to these people much easier than to adults.

Thirdly, adolescents "born digital" (Palfrey, Gasser 2008), not even remembering a time with no access to the internet and mobile devices. Contrary to the other age groups (for example, adults), they grew up into an environment where the Internet and WI-FI have been just facts of life as for us - perhaps electricity? The world without these devices would seem to them incomprehensible and unnatural; therefore, a scientific exploration of how they adapt to the cyberworld is reasonable and justifiable.

\section{Digital Technology in the World}

According to the Pew Research Center (2019) large majorities, even in developing countries, either own or share a mobile phone. Mobile devices play a prominent role in how people access the internet and social networks. Smartphone ownership can vary widely by country, even across advanced economies. While around nine-in-ten or more South Koreans (95\% population), Israelis (88\%) and Dutch (87 \%) people own smartphones, ownership rates are closer to six-in-ten in other developed nations like Poland (63\%), Russia (59\%) and Greece (59\%). However, there is a wide gap in smartphone ownership between older and younger users. Data provided by the Pew Research Center shows that, for example, in 2018 in Poland among the 50-and-older age group ownership rate was $35 \%$, while in the younger group (under 35 years) was $93 \%$. Russia presents quite similar rates: $26 \%$ in the older group and $91 \%$ in the younger group. Internet use is almost universal in most advanced economies (more than $90 \%$ of adults).

At the same time, social media use is less widespread, even though social networking sites can be accessed via smartphone as well as from other platforms. So, for example, in Russia, $63 \%$ of adults use social media, more than those who own smartphones, and in Poland, only $53 \%$ of adults do this. Again, 
younger age groups are more likely to use social media sites than older ones. In Poland, the numbers are $93 \%$ of people aged below 35, and $35 \%$ of those above 50 . In Russia, the numbers are 91\% and 26\% (Pew Research Center 2019).

\section{Digital Technology Use by Adolescents}

We might say after Madeleine George and Candice Odgers (2015): The question is no longer whether adolescents are using mobile technologies but rather how, why, and with what effects. Therefore, we have to understand what children are doing with the internet actually, how they use digital technology?

According to the research carried out in Malta, majority children aged 8-15 uses the internet daily from 2 to 5 hours: chatting, social networking, emailing, video calling, downloading films or music, watching videos online, blogging and online shopping (Lauri, Borg, Farrugia 2015). The data from the Pew Research Center report shows that $45 \%$ of teens in the US are online on a near-constant basis. Six-in-ten teenagers (60\%) spend time with their friends online on a daily or neardaily basis, while only one-quarter $(24 \%)$ report that spend time with their friend in person.

According to George and Odgers (2015), teenagers send and receive an average of over 60 text messages per day. A majority of teenagers (72\%) check their phones for messages or notifications as soon as they wake up. Fiftyeight percent feel as if they have to respond to messages from other people immediately. Thirty-one percent lose their focus in class because they are checking their smartphone.

Dutch scholars have identified several motives for children's Internet use (Valkenburg, Soeters 2001). It occurred that children's motives for using the internet and the gratifications they obtain from going online can be categorized into six groups. The most prominent motive was simply the affinity with a computer ("I like to work with computers"), the second motive was seeking information about one's idols, hobbies, also information helpful to do homework. Then, it was entertainment ("it is enjoyable, exciting"), and avoidance boredom, when children say "there is nothing else to do, there is nobody around to play with, it passes the time away." The last two motives were social: making new friends online, as well as for the sake of offline interactions ("my friends also use the Internet").

Some insight into what is interesting for teenagers on the internet we can get from the Pew Research Center (2018) report concerning the most popular online groups. The most popular groups are those that focus on hobbies and gaming (41\% of adolescents spend time in these groups) and groups focused on humor (49\%). $28 \%$ of teens chose groups interested in pop culture and sports, a bit less (26\%) - in fashion and style of life, $19 \%$ - in dating and relationships, $15 \%$ - health-related problems, $12 \%$ - people with specific characteristics, such as people of colour, LGBT people, and $8 \%$ - in groups interested in politics and religion.

Looking at the most popular among teenagers social groups, we may get the impression that the primary purpose of being online is to be entertained and have a pleasant and joyful time. However, it is not the whole truth about the cyber world in which adolescents live. As regards social media, there is also a darker side of being online. But still, $81 \%$ of teenagers say that they feel more connected to their friends, $69 \%$ think that social media help to interact with a more diverse group of people, and about the same share (68\%) of teenagers think that thanks to using online groups they have people who will support them through tough times. On the other hand, $45 \%$ feel overwhelmed by "all the drama there", whatever the drama is; $43 \%$ feel pressure to only post content that makes them look good to others, and $37 \%$ feel pressure to post content that will get a lot of likes and comments (Pew Research Center 2018).

Valkenburg and Soeters (2001) asked Dutch adolescents about a positive and negative experience with internet activities in general. As expected, as many as $46 \%$ of children reported a positive experience with playing games, video clips, songs, $26 \%$ when finding information about animals, their idols, also about sports, and $12 \%$ felt positive emotion 
during social interaction. Interestingly, majority of children (73\%) had no negative experience, and only one in twenty reported some sort of them: $10 \%$ feeling in that way when the problems with computers occurred (e.g., computer crash, virus); 4\% admitted having negative feelings about pornographic or violent content, and 2,5\% experienced online harassment.

However, the Pew Research survey conducted in March-April 2018 shows that online harassment has become a pervasive experience. As much as $59 \%$ of teenagers have been the target of cyberbullying, including offensive name-calling (reported by $42 \%$ of teens), spreading of false rumours (32\%), receiving explicit images they didn't ask for (25\%), constant asking of where they are, what they are doing, by someone other than a parent (21\%), physical threats (16\%), having explicit images of them shared without their consent (7\%).

\section{Popular Concerns About Internet Use}

It becomes understandable why dominant parents' concern about their children's internet activities is online safety. In a survey of 1,000 parents of children between 10 and 14 years of age, $63 \%$ of parents reported being extremely concerned that their child may meet a stranger online, and 1 in 3 parents was extremely concerned that their child would be a victim of cyberbullying. Many parents (69\%) also report being worried about how their children are managing their reputations online (Boyd, Hargittai 2013).

The more comprehensive review of parents' worries is presented in the paper by Madeleine George and Candice Odgers (2015). According to these authors, parents worry about whom adolescents are interacting with online and what type of information they are sharing with others; that children will be victims of cyberbullying; that being online constantly prevents children from being present in "real life" and interferes with offline socialization, experiences, and friendships. Also, parents are anxious about that mobile phones are creating a digital divide between them and their children. Another worry is that children are experimenting with alternative identities online while leaving a digital archive of data that may damage their sense of self and future lives. The serious parents' concern is that constant multitasking on mobile devices is impairing adolescents' cognitive performance. In addition to that, parents think that adolescents are losing sleep because of their devices.

Are parents' worries are justified? Goerge and Odgers (2015) address these issues by looking at the evidence from recent research.

Online interactions. Many parents report being concerned about whom their adolescents are interacting with online (Boyd, Hargittai 2013). However, research has consistently shown that online versus offline networks look very similar (Gross 2004; Reich, Subrahmanyam, Espinoza 2012). Also, most messages sent by young adolescents were positive or neutral in content, and only a small fraction of the messages contained sexual or profane language (Underwood, Ehrenreich, More, Solis, Brinkley 2015). So, we may say that there is a significant degree of overlap between online versus offline friendships and much of the content of these high frequency exchanges among younger adolescents appears to be not harmful.

Cyberbullying is one of the few areas in which a substantial amount of data regarding the possible effects of online interactions on adolescents' lives now exists. In popular opinion the experience of cyberbullying has been linked with a host of adverse outcomes for both individuals and organizations (e.g., schools), including anxiety, depression, substance abuse, difficulty sleeping, increased physical symptoms, decreased performance in school, absenteeism, and truancy, dropping out of school, and murder or suicide. A recent meta-analysis of 131 studies by Kowalski, Giumetti, Schroeder and Lattanner (2014) confirms this opinion, at least to some extent. Indeed, adolescents who experience cyberbullying are at increased risk for a wide range of mental and physical health problems. Also, it occurred that estimates of victimization related to cyberbullying among adolescents typically fall between $10 \%$ and $40 \%$ but vary widely depending on the definition of cyber- 
bullying, the age and characteristics of adolescents, and the reporting time frame. There is a substantial degree of overlap between adolescents who bully others offline and those who engage in cyberbullying; similarly, victims of cyberbullying are often victimized offline.

Virtual vs. the real world. Early research on the internet in the 1990s tended to support the idea that online social interactions were occurring at the expense of existing relationships. Today, most adolescents are online, and most online exchanges occur among peers who also identify as friends offline. Time spent online may displace in-person interactions, but there is little evidence that it reduces friendship quality or leads to social isolation. For the most part, adolescents appear to be using mobile technologies to communicate and stay connected to existing friends and, in turn, may be strengthening the quality of existing relationships.

Relationships with parents. Technology use among adolescents may take away from time spent with parents, but it does not necessarily weaken the parent-child relationship. Existing evidence suggests that if the quality of the parent-child relationship is strong offline, then new technologies may bring benefits. Again, parallels are seen between the relationships that adolescents have in their offline versus online lives.

Identity exploration. Most research has shown that there is considerable overlap in how individuals present themselves to others both online and offline. Narrative studies also suggest that online spaces may offer safe places for some young people to explore sensitive topics about their sexuality and identity (Harper, Bruce, Serrano, Jamil 2009). Access to the online world may also spark new interests and allow some adolescents to try out new identities (Valkenburg, Schouten, Peter 2005). For example, adolescents in this study, especially girls and younger adolescents, pretended to be older or more attractive to see how others online might react to them differently.

Multitasking. Adolescents report using new technologies to multitask-for example, talking to a friend while completing their homework online (Gross 2004). Research with college students suggests that multitasking associated with new technologies could have negative effects. For example, college students classified as "heavy users" of new technologies tend to exhibit more academic impairments-such as lower course grades (Englander, Terregrossa, Wang 2010), less time spent studying (Kirschner, Karpinski 2010), and a higher number of missed classes - compared with adolescents with average or low usage of new technologies.

Sleep issues. Adolescents require between 8,5 and $10 \mathrm{hr}$ of sleep per night; yet, most adolescents (58\%) are sleeping $7 \mathrm{hr}$ or less per night. Poor sleep habits can lead to physical and mental health problems and are associated with reduced cognitive performance (Dahl, Lewin 2002). Research to date has consistently shown that mobile device and media usage before bedtime is associated with reduced sleep time and quality.

\section{Digital Technology Good or Bad for Adolescents?}

George and Odgers (2015) conclude that, although there are cases in which new technologies have introduced new risks to adolescent well-being (e. g., by creating a new platform for bullying, interfering with sleep, damaging one's reputation), most behaviors and risks that are present in the online world appear to be mirrored offline. That is, although new technologies are offering new platforms for adolescents to interact with each other, online behaviors can often be predicted by offline behaviors and personal characteristics. Authors also suggest that the effects of new technologies on adolescent development are not uniform. Adolescents with strong familial and peer relationships exhibit enhanced relationship quality when virtual interactions are also present (Valkenburg, Peter 2007). In contrast, for adolescents who are struggling within existing relationships, high levels of technology use predict lower well-being and relationship quality (Weisskirch 2009). Similarly, shy or isolated adolescents may seek out online interactions to decrease loneliness or to build skills (Bardi, Brady 2010), whereas 
among adolescents with low quality friendships, time spent online for noncommunicative purposes predicts more depression and social anxiety over time (Selfout, Branje, Delsing, Bogt, Meeus 2009; Błachnio, Przepiórka, Pantic 2015).

Scholars have disputed most of the described above negative consequences and many studies show how digital technology brings significant benefits to children (Byrne et al. 2016); highlighting its social and interactive features (Boyd 2014), how it opens up new opportunities for performance, creativity, and expression, and features as an everyday practice in the home for purposes of social interaction and relaxation with the family (Enevold 2012). Recent research suggests that video gaming positively influences cognitive, motivational, emotional and social development (Boyd 2014).

Valkenburg and Peter (2007) found positive associations among the time adolescents spent online, frequency of chats with friends, quality of friendships, and well-being. In particular, they found a moderating effect of type of online communication on adolescents' wellbeing: Instant messaging, which was mostly used to communicate with existing friends, positively predicted well-being. Chat in a public chatroom, which was relatively often used to talk with strangers, did not affect adolescents' well-being.

Best, Manktelow and Taylor (2014), in a systematic review of the literature (43 papers published between 2003 and 2013) found that the majority of included papers reported either mixed or no effect(s) of social media on adolescent well-being. The findings in this review indicate that possible benefits of online social networking are the following: Social media use may enhance one's self-esteem which mainly is associated with online activities such as chatting with peers or strangers or receiving support when distressed. It may increase one's social capital, bridging capital, in particular, that is, connections that link people belonging to different social - race, class, religion - groups. It may also grant a feeling of safety while experimenting with one's identity. Increased chances for self-disclosure, due to online anonymity, may have a positive impact on some emotional and psychological problems.

Generally speaking, social media technology allow adolescents to increase the size and composition of their social networks substantially. This may be either beneficial (e.g., increased social capital, social support, etc.) or harmful through increased exposure to triggering or abusive content or the promotion of negative coping strategies. However, the majority of the studies analyzed by Best, Manktelow and Taylor (2014) showed no significant impact on adolescent's well-being.

In the literature review, elaborated for UNICEF, Daniel Kardefelt-Winther asks the question: How does the time children spend using digital technology impact their mental well-being, social relationships, and physical activity (Kardefelt-Winther 2017)? He suggests that moderate use of digital technology tends to be beneficial for children's mental well-being, while no use or too much use can have a small negative impact. It seems that in order to improve children's mental well-being, it is more important to focus on other factors such as family functioning, social dynamics at school and socioeconomic conditions, while also ensuring that children use digital technology in moderate amounts. Also, again, the evidence reviewed by Kardefelt-Winther shows mostly positive outcomes from using digital technology in terms of children's social relationships. As regards the impact on children's physical activity, the evidence is mixed. While some studies found that time children spent using digital technology were associated with a reduction in physical activity, other studies suggested that this relationship is not direct and that other factor could be more important.

\section{Concluding Remarks}

How can I answer the question posed in the title of this paper - Is cyber world ally or enemy? Let us read a few sentences that I found in the paper by Raphael Cohen-Almagor, professor of School of Politics, Philosophy and International Studies, University of Hull, UK. 
"The internet is a vast ocean of knowledge, data, ideologies, and propaganda. It is ubiquitous, interactive, fast, and decentralized. The ease of access to the internet, its low cost and speed, its chaotic structure (or lack of structure), the anonymity which individuals and groups may enjoy, and the international character of the World Wide Web furnish all kinds of individuals and organizations an easy and effective arena for their partisan interests. The internet contains some of the best written products of humanity, and some of the worse ones. It serves the positive and negative elements in society" (Cohen-Almagor 2015, 161-162).
That is true. Technology is not positive or negative, good or bad, it is neutral until people give meaning and place a value on it. We should not idealize, nor demonize cyber world in which our children are immersed. We, adults, parent, and teachers are bombarded with stories on how new technologies are destroying the mental, emotional, social lives of children which is possible, but not inevitable. Digital technology has advantages as well as challenges. It is our responsibility to make it work for the benefits of our children, to make it an ally.

\section{References}

Best, P., Manktelow, R., Taylor, B. (2014) Online communication, social media and adolescent well-being: A systematic narrative review. Children and Youth Services Review, vol. 41, pp. 27-36.

Błachnio, A., Przepiórka, A., Pantic, I. (2015) Internet use, Facebook intrusion, and depression: results of a cross-sectional study. European Psychiatry, vol. 30 (6), pp. 681-684.

Boyd, D. (2014) It's complicated. The social lives of networked teens. New Haven \& Lonodn: Yale University Press.

Boyd, D., Hargittai, E. (2013) Connected and concerned: Variation in parents' online safety concerns. Policy and Internet, vol. 5, pp. 245-269.

Byrne, J., Kardefelt-Winther, D., Livingstone, S. et al. (2016) Global Kids Online research synthesis, 2015-2016. UNICEF and London School of Economics and Political Science.

Cash, H., Rae, C., Steel, A., Winkler, A. (2012) Internet addiction: A brief summary of research and practice. Current Psychiatry Reviews, vol. 8 (4), pp. 292-298.

Cohen-Almago R. (2015) Internet architecture, freedom of expression and social responsibility: critical realism and proposals for a better futur. Innovation: The European Journal of Social Science Research, vol. 28 (2), pp. 147-166.

Dahl, R., Lewin, D. S. (2002) Pathways to adolescent health: Sleep regulation and behavior. Journal of Adolescent Health, vol. 31, pp. 175-184.

Enevold, J. (2012) Domesticating play, designing everyday life: the practice and performance of family gender, and gaming. In: Raine, K., Frans, M, Jaakko, S (eds.) Proceedings of 2012 DiGRA Nordic (1-13). Tampere: University of Tampere.

Englander, F., Terregrossa, R. A., Wang, Z. (2010) Internet use among college students: Tool or toy? Educational Review, vol. 62, pp. 85-96.

Erikson E. H. (1968) Identity, youth, and crisis. New York, N.Y.: Norton.

Eurostat (2019). [Online]. Available at: https://ec.europa.eu/eurostat/statisticsexplained/index.php/Digital_economy_and_society_statistics_-_households_and_individuals\# Internet_usage (assessed 16.09.2019).

George, M., Odgers, C. L. (2015) Seven fears and the science of how mobile technologies may be influencing adolescents in the digital age. Perspectives on Psychological Science, vol. 10 (6), pp. 832-851.

Gross, E. F. (2004) Adolescent internet use: What we expect, what teens report. Journal of Applied Developmental Psychology, vol. 25, pp. 633-649. 
Harper, G. W., Bruce, D., S. P., Jamil, O. (2009) The role of the Internet in the sexual identity development of gay and bisexual male adolescents. In: Hammack, P. L., Cohler, B. J. (eds.) The story of sexual identity: Narrative perspectives on the gay and lesbian life course (pp. 297326). New York, N.Y.: Oxford University Press.

Kardefelt-Winther, D. (2017) How does the time children spend using digital technology impact their mental well-being, social relationships and physical activity? An evidence-focused literature review. Florence: UNICEF Office of Research - Innocenti.

Kirschner, P. A., Karpinksi, A. C. (2010) Facebook and academic performance. Computers in Human Behavior, vol. 26, pp. 1237-1245.

Kowalski, R. M., Giumetti, G. W., Schroeder, A. N., Lattanner, M. R. (2014) Bullying in the digital age: A critical review and meta-analysis of cyberbullying research among youth. Psychological Bulletin, vol. 140 (4), pp. 1073-1137.

Palfrey, J. G., Gasser, U. (2008) Born digital: Understanding the first generation of digital natives. New Yor, NY: Basic Books.

Pew Research Center (2018). [Online]. Available at: https://www.pewinternet.org/2018/ 03/01/social-media-use-in-2018/ (assessed 16.09.2019).

Pew Research Center (2019). [Online]. Available at: https://www.pewresearch.org/global/ 2019/02/05/ (assessed 16.09.2019).

Reich, S. M., Subrahmanyam, K., Espinoza, G. (2012) Friending, IMing, and hanging out face-toface: Overlap in adolescents' online and offline social networks. Developmental Psychology, vol. 48, pp. 356-368.

Selfout, M. H., Branje, S. J., Delsing, M., Bogt, T. F., Meeus, W. H. (2009) Different types of Internet use, depression, and social anxiety: The role of perceived friendship quality. Journal of Adolescence, vol. 32, pp. 819-833.

Underwood, M. K., Ehrenreich, S. E., More, D., Solis, J. S., Brinkley, D. Y. (2015) The BlackBerry Project: The hidden world of adolescents' text messaging and relations with internalizing symptoms. Journal of Research on Adolescence, vol. 25, pp. 101-117.

Valkenburg, P. M., Peter, J. (2007) Online communication and adolescent well-being: Testing the stimulation versus the displacement hypothesis. Journal of Computer-Mediated Communication, vol. 12 (4), pp. 1169-1182.

Valkenburg, P. M., Soeters, K. E. (2001) Children's positive and negative experiences with the Internet. An exploratory survey. Communication Research, vol. 28 (5), pp. 652-675.

Valkenburg, P. M., Schouten, A. P., Peter, J. (2005) Adolescents' identity experiments on the Internet. New Media and Society, vol. 7, pp. 383-402.

Weisskirch, R. S. (2009) Parenting by cell phone: Parental monitoring of adolescents and family relations. Journal of Youth and Adolescence, vol. 38, pp. 1123-1139. 